\title{
Impact of Educational Program for Deaf Students knowledge regarding healthy food ingredients in Khartoum State
}

\author{
Nayf khaled Altoani MS* \\ Department of Community Health Nursing Faculty of Nursing, Al Neelain University Sudan
}

Article History

Received: 30.03 .2020

Accepted: 24.04 .2020

Published: 26.10.2020

Journal homepage:

https://www.easpublisher.com/easjnm

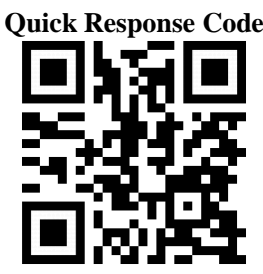

Abstract: Background: Healthy eating contributes to an overall sense of well-being, and is a cornerstone in the prevention of a number of conditions, including heart disease, diabetes, high blood pressure, stroke, cancer, dental caries and asthma. For children and young people, healthy eating is particularly important for healthy growth and cognitive development. Eating behaviours adopted during this period are likely to be maintained into adulthood, underscoring the importance of encouraging healthy eating as early as possible $[1,2]$. Many adult deaf since birth or early child childhood have poor knowledge of healthy eating has adversely affected deaf people's nutritional health results from limited access to information that is considered common knowledge among hearing persons. For example, never overheard parents discussing about healthy eating [3]. Method: This study was conducted to determine changes in healthy food ingredients knowledge for deaf students in classes 6 and 7 after receiving a nutrition education program. (144) Deaf students studying at $\mathrm{Al} \mathrm{Aaml} \mathrm{schools} \mathrm{were} \mathrm{included} \mathrm{in} \mathrm{the} \mathrm{study.} \mathrm{The} \mathrm{students} \mathrm{were} \mathrm{divided} \mathrm{into} \mathrm{two} \mathrm{groups;}$ an intervention group comprised of 72 students and control group that comprised of another 72 students. The program was conducted for 6 weeks which comprised of two parts; lectures, practical session (computer training) and a quiz at the end of the program. Questionnaires to assess Knowledge of deaf students were distributed to students before the intervention program, and after intervention. Data was analysed using statistical analysis program (SPSS). Ethical approval was obtained from Al Neelain IRB and permission from $\mathrm{Al}$ Amal schools. Informed consent was obtained from parents of the deaf student $\mathrm{s}$ and assent from the students themselves. Results: show significant differences in experimental group between pretest where the mean value located in the fair range according to the tripartite Likert test of $1.67-2.33$, and posttest where majority of students' responses in the range between 2.34 -3 and indicate to good knowledge. Results show also no significant differences in control group between pretest and posttest where the means value located in the fair range according to the tripartite Likert test of $1.67-2.33$. Conclusion and recommendation: The study concluded that the education program has a positive impact on the knowledge of deaf students regarding healthy food ingredients in Khartoum state, and we recommend replication of similar studies in other topics and districts in Sudan especially in Alaml schools.

Keywords: Healthy food, deaf Students, and health education.

Copyright (C) 2020 The Author(s): This is an open-access article distributed under the terms of the Creative Commons Attribution 4.0 International License (CC BY-NC 4.0) which permits unrestricted use, distribution, and reproduction in any medium for non-commercial use provided the original author and source are credited.

\section{INTRODUCTION}

Healthy eating is consuming the right quantities of foods from all food groups in order to ensure an individual's body is appropriately nourished and capable of functioning appropriately, dependent on lifestyle and activity levels [4-6].

Youth face a number of food related concerns, such as poor nutrition, obesity, and hunger. In 2010, more than one-third of U.S. children and adolescents were overweight or obese [7].

As the relationships among diet, health, and disease prevention have become clearer, nutrition education and the promotion of healthy eating behaviours and lifestyles continue to receive increased attention. In its broadest sense, Education of the population about food processing and consumption may be very important in ensuring the best use of the available food [8].

Much has been written over the years about the relationship, uniqueness and overlap between health education, health promotion and other concepts, such as health literacy, primary health care, community development and mobilization, and the role of empowerment [9].

Many adults' deaf since birth or early childhood have low health literacy. This low health 
literacy resulted from a lifetime of limited access to information that is often considered common knowledge among hearing persons [10].

Children with various disabilities are taught to use computers in their daily activities such as education, work, home appliances' control (turning lights, radio, TV...), communication and entertainment [11].

This study aimed to answer the following questions: Is there an impact of educational program for deaf students regarding knowledge on malnutrition in Khartoum State?

\section{METHODOLOGY}

This intervention quasi experimental facility based study conducted to determine changes in deaf student's knowledge regarding healthy food ingredients in classes 6 and 7 after receiving a nutrition education program in Khartoum State. The study included 144 students that were divided equally into two groups, 72 students for the intervention group and 72 students for the control group from Al Aaml schools in Omdurman and Khartoum three participated in study. The experimental group in the schools received nutrition education program over a period of 6 weeks, while the control group did not receive program. The educational program consisted in two parts; lectures and practical sessions. The program started with the lectures first, two lectures were presented to the student; every lecture was about one hour long, one lectures pre week. The practical part consisted of computer training which was presented mainly principles of computer use for all members in experimental group in two hours after that each student opened computer and use cd-room with one of the research teams. After that Electronic application included (text, pictures, questions, and answers and feedback about healthy food) distributed to every student in experimental groups and let students used it for three weeks before final data collection. The questionnaire to assess deaf students Knowledge was distributed before and after intervention program. Data were analyzed using SPSS (Statistical Package for Social Sciences). Results of the Chi test for the responses of the sample show a significant statistical differences ( $\mathrm{p}$-value 0.000), among experimental group (pre and post) educational program. Results also show no significant statistical differences (p-value 0.000), among control group (pre and post) educational program. Ethical approval was obtained from Al Neelain (I R B), the parents of the students were asked to sign the informed consent form after the purpose of the study had been explained to them, and the anonymity and confidentiality of responses, voluntary participation and right to withdrawal from study were emphasized. Assent of the students also taken in within form.

\section{RESULTS}

The tripartite Likert test to identify Knowledge level by weighed mean average was as follows:

\begin{tabular}{|l|l|}
\hline Levels & Mean weight average \\
\hline low & $1-1.66$ \\
\hline Fair & $1.67-2.33$ \\
\hline Good & $2.34-3$ \\
\hline
\end{tabular}

\section{Demographic data tables}

Table-1

\begin{tabular}{|r|l|r|r|r|r|}
\hline \multicolumn{7}{|c|}{ Schools } \\
\hline \multirow{3}{*}{ Valid } & AL-Amal Khartoum & 60 & Percent & Valid Percent & Cumulative Percent \\
\cline { 2 - 6 } & AL-Amal Omdurman & 84 & 51.7 & 41.7 & 41.7 \\
\cline { 2 - 6 } & Total & 144 & 100.0 & 58.3 & 100.0 \\
\hline
\end{tabular}

(144) deaf students form Al Amal schools, (60) students from Khartoum three school, (44) from Omdurman school.

Table-2

\begin{tabular}{|c|c|c|c|c|c|}
\hline \multicolumn{6}{|c|}{ Class } \\
\hline & & $\mathrm{N}$ & Percent & Valid Percent & Cumulative Percent \\
\hline \multirow[t]{3}{*}{ Valid } & 7 th & 76 & 52.8 & 52.8 & 52.8 \\
\hline & 8th & 68 & 47.2 & 47.2 & 100.0 \\
\hline & Total & 144 & 100.0 & 100.0 & \\
\hline
\end{tabular}

The majority of students (59\%) were males, and (41\%) were females. 
Table-3

\begin{tabular}{|c|c|c|c|c|c|}
\hline \multicolumn{6}{|c|}{ Gender } \\
\hline & & $\mathrm{N}$ & Percent & Valid Percent & Cumulative Percent \\
\hline \multirow[t]{3}{*}{ Valid } & Male & 85 & 59.0 & 59.0 & 59.0 \\
\hline & Female & 59 & 41.0 & 41.0 & 100.0 \\
\hline & Total & 144 & 100.0 & 100.0 & \\
\hline
\end{tabular}

In this study, $(52,8 \%)$ students were in 6 th class and $(47,2 \%)$ in 7 th.

Table-4: Experimental group knowledge regarding healthy food ingredients

\begin{tabular}{|l|l|l|l|l|l|l|l|l|l|}
\hline Test & $\mathbf{N}$ & Frequency & Incorrect & $\begin{array}{l}\text { Don't } \\
\text { know }\end{array}$ & Correct & Mean & Deviation & Chi & P \\
\hline Pre & 72 & 288 & $54.51 \%$ & $12,84 \%$ & $32.63 \%$ & 1.86 & 0.93 & 454.321 & 0.000 \\
\hline post & 72 & 288 & $27.08 \%$ & $14,93 \%$ & $57.89 \%$ & 2.66 & 0.88 & 454.321 & 0.000 \\
\hline
\end{tabular}

Table (4) show the Chi test in the pretest was 454.321 with a mean of 1.86 with a standard deviation of 0.93 . The value of the Chi test in the post-test was 454.321 with a mean of 2.66 with a standard deviation of 0.88 .

We conclude from the above that there are significant differences in the pretest group where the mean value is 1,86 and it is located in the fair range according to the tripartite Likert test of $1.67-2.33$.

The majority of respondents' responses to the post-test was 2.66 in the range between $2.34-3$ and indicates good knowledge.

Table-6: Control group knowledge regarding healthy food ingredients

\begin{tabular}{|l|l|c|l|l|l|l|l|l|l|}
\hline Test & n & Frequency & Incorrect & Don't know & Correct & Mean & Deviation & Chi & p \\
\hline Pre & 72 & 1872 & $52.43 \%$ & $13.54 \%$ & $34,03 \%$ & 1.81 & 0.93 & 411.433 & 0.000 \\
\hline post & 72 & 1872 & $53.81 \%$ & $12.15 \%$ & $34.04 \%$ & 1.77 & 0.93 & 407.249 & 0.000 \\
\hline
\end{tabular}

Table (6) show the Chi test in the pretest was 411.433 with a mean of. 1.82 With a standard deviation of 0.93 . The value of the Chi test in the post-test was 407.249 with a mean of 1.84 with a standard deviation of 1.84 .

We conclude from the above that there are significant differences in the pretest group indicating where the mean value is 1,82 and it is located in the fair range according to the tripartite Likert test of 1.67 2.33

The majority of responses to the post-test were 1.84 in the range between $1.67-2.33$ and indicate fair knowledge too.

\section{DISCUSSION}

This study conducted to identify impact of educational program for deaf students regarding knowledge of healthy food ingredients in Khartoum State. Healthy food ingredients knowledge of deaf students was test with 6 questions. Results show significant statistical differences among study experimental groups (pre and post) education program. Are significant differences in the posttest group indicating fair knowledge where the mean value is 1,86 and it is located in the fair range according to the tripartite Likert test of $1.67-2.33$. The majority of respondents' responses to the post-test was 2.66 in the range between 2.34 - 3 and indicates good knowledge.
The result also shows majority of the responses of the control group pre and post tests were in the extent of the fair knowledge according to the test of the triple Likert from 0 - 1.66. Data showed there was significant improvement in students' nutrition knowledge before and after attending educational program form fair to good in experimental group. When compared to similar study [9] conducted in Egypt to improve the nutrition awareness and nutritional status of students with hearing impairment. Which showed significant improvement in information (improving the degree of nutritional information from (19.74) before the program to $(39,17)$ after program, as well as improving the degree of dietary behaviour and habits from (27 to 29,5) degree to $(34,12$ to 35,48$)$ degree before and after the program respectively. Another study [10] in Lebanon to evaluated the impact of a 6-month school nutrition intervention on changes in dietary knowledge, attitude, behavior (KAB) and nutritional status of Syrian refugee children. That fined significant increases in dietary knowledge in experimental group. According to the result of the study and other studies positive impact of health education program is clear, but this effect varies according to the circumstances (place, sample characteristics, tools) surrounding each study. Study has shown that a well-executed education program could improve students' knowledge towards healthy food ingredients. In addition, the usage of educational technology such as $\mathrm{CD}$ in this program may attract children's attention to learn and understand better. This program could be adapted by other schools for deaf 
students in Sudan. By implementing the program in schools, it will give a positive impact by inculcating good nutrition knowledge in deaf students, and that hopefully will persist throughout their lives. It is recommended Replication of similar studies in other topics and districts in Sudan especially in Alamal schools.

\section{REFERENCES}

1. Krebs-Smith, S. M., Heimendinger, J., Patterson, B. H., Subar, A. F., Kessler, R., \& Pivonka, E. (1995). Psychosocial factors associated with fruit and vegetable consumption. American Journal of Health Promotion, 10(2), 98-104.

2. Contento, I. R. (2011). Nutrition Education: Linking Research, Theory, and Practice (2nd edition). Sudbury, MA: Jones and Bartlett Publishers.

3. Barnett, S., McKee, M., Smith, S. R., \& Pearson, T. A. Deaf Sign Language Users, Health Inequities, and Public Health: Opportunity for Social Justice Posted on February 15, 2011 by.

4. Lupton, J. R., Brooks, J. A., Butte, N. F., Caballero, B., Flatt, J. P., \& Fried, S. K. (2002). Dietary reference intakes for energy, carbohydrate, fiber, fat, fatty acids, cholesterol, protein, and amino acids. National Academy Press: Washington, DC, USA, 5, 589-768.
5. Best, C. (Ed.). (2008). Nutrition: a handbook for nurses (Vol. 22). John Wiley \& Sons.

6. NHS Website (2014). Food and diet [online].

7. Second Harvest Heartland. (2013). Hunger facts. Retrieved from: http://www.2harvest.org/pdf/hunger_facts_2013.pd $\mathrm{f}$

8. Contento, I.R. (2011). Nutrition Education: Linking Research, Theory, and Practice (2nd edition). Sudbury, MA: Jones and Bartlett Publishers.

9. Downie, R.S., Fyfe, C., Tannahill, A. (1990). Health promotion: models and values. Oxford, Oxford University Press.

10. University of Waikato. (2002). Greenstone Digital Library Software. Retrieved February 11, 2003, from http://www.greenstone.org/english/home.html.

11. Abeer, Mustafa, A.K. (2017). Effect of Nutrition Education on hearing handicapped students in preparatory stage. Thesis (Ph.D.) Aeen shames University. Faculty of Education.

12. Harake, E., Diab, M., Kharroubi, S., Hamadeh, S. K., \& Jomaa, L. (2018). Impact of a pilot schoolbased nutrition intervention on dietary knowledge, attitudes, behavior and nutritional status of syrian refugee children in the Bekaa, Lebanon. Nutrients, 10(7), 913. 